\title{
THE EFFECT OF BASIC LIFE SUPPORT (BLS) TRAINING IN THE KNOWLEDGE AND SKILL LEVEL OF COMMUNITY IN SIDODADI VILLAGE, LAWANG, INDONESIA
}

\author{
Maria Arni Stella ${ }_{2}$ Prima Hapsari Wulandari ${ }^{1}$, Tantri Adhiatama Lukitaningrum Subianto ${ }^{1}$ \\ Farah Adiba Binti Mohamad Jahari ${ }^{1}$, Aida Nur Aisyah ${ }^{1}$, Isna Mahmudah ${ }^{1}$, Steven Sandjaja ${ }^{1}$, \\ Septian Dwi Prabowo ${ }^{1}$, Djohar Nuswantoro ${ }^{2}$, Heri S. Widodo ${ }^{3}$ \\ ${ }^{1}$ Faculty of Medicine, Universitas Airlangga, Surabaya, Indonesia \\ ${ }^{2}$ Department of Public Health Science, Faculty of Medicine, Universitas Airlangga, Surabaya, Indonesia \\ ${ }^{3}$ Murnajati Public Health Training Centre, Malang, Indonesia \\ aCorresponding author: mariaarnistella@gmail.com
}

\section{ABSTRACT}

Introduction: About 300.000 - 350.000 Indonesian people suffer from cardiac arrest each year. Basic Life Support (BLS) is the first immediate response needed by cardiac arrest people, especially the out of hospital cardiac arrest (OHCA) patient. BLS that given from public to OHCA could increase the survival rate up to $2-3 \mathrm{x}$ higher. Unfortunately, the Indonesian still did not know what is cardiac arrest, how to recognize it, and how to do BLS. Objective: The objective of this study was to identify the effect of BLS training in the knowledge and skill level of community in Sidodadi Village, Lawang, Indonesia. Method and Material: This experiment used a quasi-experimental design with 102 of the random sampling of people age 20-40 in Sidodadi Village, Lawang, Indonesia. The sample was given pre-test and post-test knowledge questioner before and after joining BLS training. The sample's skill was scored by an assistant doctor using a skill checklist. The data then analysed with a t-paired sample test, Wilcoxon sum rank test, and Pearson correlation. Result and Discussion: The score of women is higher than men both in pre-test and post-test, with the significance of $\mathrm{p}=0,039$ for pre-test and $\mathrm{p}=0,001.99 \%$ who joined BLS training have a significant increase in knowledge with $\mathrm{p}=0,001$. Conclusion: The increase in knowledge and skill is correlated for an excellent and good level of the score, but not correlated in a bad level. About $99 \%$ of people who have joined BLS training have a significant increase in knowledge and skill. These trained people have the willingness to be a bystander for cardiac arrest people near them.

Keywords: Basic Life Support Training; Skill; Knowledge; BLS; Bystander

ABSTRAK

Pendahuluan: Sekitar 300.000 - 350.000 masyarakat Indonesia mengalami henti jantung setiap tahunnya. Basic Life Support (BLS) adalah pertolongan pertama yang diperlukan oleh korban henti jantung, terutama henti jantung yang terjadi diluar rumah sakit (out of hospital cardiac arrest-OHCA). BLS yang diberikan oleh awam pada OHCA mampu meningkatkan survival rate sebanyak 2 hingga 3x lipat. Sayangnya, masyarakat Indonesia masih banyak yang belum mengetahui apa itu henti jantung, bagaimana cara mengenalinya, dan bagaimana cara melakukan BLS. Tujuan: Tujuan penelitian ini adalah untuk mengetahui pengaruh pelatihan BLS terhadap tingkat pengetahuan dan keterampilan masyarakat dalam memberikan pertolongan pertama henti jantung di Desa Sidodadi, Kecamatan Lawang, Indonesia. Metode dan Bahan: Penelitian ini menggunakan desain quasi eksperimental dengan 102 random sampling dari penduduk berusia 20-40 tahun di Desa Sidodadi, Kecamatan Lawang, Indonesia. Sampel diminta untuk mengisi pretest pengetahuan, mengikuti pelatihan BLS, dan mengisi posttest pengetahuan. Keterampilan sampel dinilai oleh dokter muda menggunakan ceklis keterampilan. Data dianalisis dengan uji t berpasangan, wilcoxon sum rank test, dan uji korelasi pearson. Hasil dan Pembahasan: Nilai pretest dan postest perempuan lebih tinggi daripada pria, dengan nilai signifikansi $\mathrm{p}=0,039$ untuk pretest dan $\mathrm{p}=0,001$. $99 \%$ peserta yang mengikuti pelatihan BLS mengalami peningkatan pengetahuan yang signifikan, dengan $\mathrm{p}=0,001$. Kesimpulan: Peningkatan pengetahuan dan keterampilan memiliki korelasi, terutama pada kelompok dengan nilai pengetahuan yang baik dan sangat baik, namun tidak berkorelasi pada kelompok nilai yang buruk. 99\% peserta yang mengikuti pelatihan BLS mengalami peningkatan pengetahuan dan

Available at https://e-journal.unair.ac.id/IJAR 
keterampilan yang signifikan. Awan terlatih ini memiliki peningkatan kemauan untuk menjadi bystander dan memberikan BLS pada korban henti jantung di sekitar mereka.

Kata Kunci : Pelatihan Basic Life Support; BLS; Pengetahuan; Keterampilan; Bystand

Article info: Received 24 October 2019; Received in revised from 5 November 2019; Accepted 13 December 2019

\section{INTRODUCTION}

Cardiac arrest is one of the leading causes of death in the various Countries ${ }^{6} 300,000-$ 350,000 Indonesian communities suffer heart attacks every year. ${ }^{8}$ Basic Life Support is an action that can be given by health workers or laypeople who can be trained for heart attacks, respiratory failure, or obstructive airway breath patients. ${ }^{2}$ BLS provided by laypeople can increase 2 to 3 times of the survival rate. Anyone can do the BLS training. Teenagers between the ages of 13 to 14 years can even do chest compressions as well as adults. ${ }^{9}$ Unfortunately there are still many Indonesians who don't know what a heart attack is, how to recognize it, and how to do BLS.

The purpose of this study was to determine the effect of BLS training on the level of community knowledge and skills providing first-aid cardiac arrest in the village of Sidodadi, Lawang, Indonesia.

\section{MATERIAL AND METHOD}

The design of this study was Quasiexperimental involving the villagers of Sidodadi, Lawang, East Java, Indonesia. About 102 samples were taken randomly using simple random samples from people aged 20-40 years in the village. The exclusion criteria for the sample are residents who work in the health sector or have not attended training from the beginning to the end.

Samples were asked to fill in a pre-test knowledge level questionnaire, then they would get Basic Life Support (BLS) training for one hour, and then return to fill in the post-test knowledge level questionnaire. The value of pre-test and post-test knowledge will be compared. Samples skills were assessed by young doctors using the BLS skills checklist. The level of knowledge was taken with a BLS layman questionnaire and a BLS assessment skills sheet from the Department of Anaesthesiology and Reanimation of Dr. Soetomo General Hospital. Data knowledge was tested by paired-sample $\mathrm{t}$ test and Wilcoxon rank-sum test. Meanwhile, skills data are related to knowledge and tested with the Pearson Correlation test.

\section{RESULT AND DISCUSSION}

A total of 102 participants consisted of 47 male participants and 55 female participants in two groups. The level of knowledge of each participant's questionnaire was evaluated and then the average of each group was calculated to compare the group's average results before and after receiving BLS training. The results of the second group pre-test were compared and tested with the Wilcoxon Range Sum Test and obtained the following results:

Table 1. The Comparison Between Male and Female's Knowledge Pretest Score

\begin{tabular}{lcllll}
\hline Gender & $\mathbf{N}$ & $\begin{array}{l}\text { The } \\
\text { Average of } \\
\text { Ranking }\end{array}$ & $\begin{array}{l}\text { The Sum } \\
\text { Of Ranking }\end{array}$ & Sig. \\
\hline Male & 47 & 21.44 & 536.00 & 0.039 \\
Female & 47 & 17.43 & 244.00 & \\
\hline
\end{tabular}

Table 1 shows that the value of knowledge pre-test participants is better men than pre-test knowledge participants are women. This comparison is significant with $\mathrm{p}=0.039$. 
Table 2. The Comparison Between Male and Female's Knowledge Posttest Score

\begin{tabular}{lllll}
\hline Gender & N & $\begin{array}{l}\text { The } \\
\text { Average of } \\
\text { Ranking }\end{array}$ & $\begin{array}{l}\text { The Sum Of } \\
\text { Ranking }\end{array}$ & Sig \\
\hline Male & 47 & 23.50 & 1081.00 & 0.001 \\
Female & 47 & 47.00 & 47.00 & \\
\hline
\end{tabular}

Table 2 shows that the value of men's posttest knowledge is better than the pre-test knowledge of women. This comparison is significant with $\mathrm{p}=0.0001$.

The researchers also made a comparison between the level of knowledge before and after getting BLS training with paired-sample t-test and obtained the following results:

Table 3. The Value of Male Knowledge Level's T-Test

\begin{tabular}{|c|c|c|c|c|c|c|}
\hline Age & $\begin{array}{l}\text { Pre-test/ } \\
\text { Post-test }\end{array}$ & $\mathbf{N}$ & Mean \pm SD & Difference & T Value & $\mathbf{P}$ \\
\hline $20-25$ & $\begin{array}{l}\text { Pre-test } \\
\text { Post-test }\end{array}$ & 29 & $\begin{array}{c}6.93 \pm 1.981 \\
12.69 \pm 1.147\end{array}$ & -5.76 & -14.004 & 0.001 \\
\hline $26-30$ & $\begin{array}{l}\text { Pre-test } \\
\text { Post-test }\end{array}$ & 12 & $\begin{array}{c}6.33 \pm 2.498 \\
11.83 \pm 3.271\end{array}$ & -5.50 & -3.482 & 0.001 \\
\hline $31-35$ & $\begin{array}{l}\text { Pre-test } \\
\text { Post-test }\end{array}$ & 6 & $\begin{array}{c}6.5 \pm 2.168 \\
12.33 \pm 1.366\end{array}$ & -5.83 & -2.622 & 0.001 \\
\hline Total & $\begin{array}{l}\text { Pre-test } \\
\text { Post-test }\end{array}$ & 47 & $\begin{array}{c}6.72 \pm 2.113 \\
12.43 \pm 2.030 \\
\end{array}$ & -5.71 & -2.990 & 0.001 \\
\hline
\end{tabular}

Table 4. The Value of Female Knowledge Level's T-Test

\begin{tabular}{cllcccc}
\hline \multirow{2}{*}{ Age } & $\begin{array}{r}\text { Pre-test/ } \\
\text { Post-test }\end{array}$ & $\mathbf{N}$ & Mean \pm SD & Difference & T Value & P \\
\hline \multirow{2}{*}{$20-25$} & Pre-test & 2 & $7.41 \pm 2.806$ & -4.04 & -7.973 & 0.001 \\
& Post-test & 2 & $11.45 \pm 1.471$ & & & \\
\multirow{2}{*}{$26-30$} & Pre-test & 1 & $6.06 \pm 2.53$ & -4.99 & -7.813 & 0.001 \\
& Post-test & 7 & $11, .59 \pm 1.805$ & & & \\
\multirow{2}{*}{$31-35$} & Pre-test & 7 & $5.71 \pm 3.039$ & -5.58 & -4.324 & 0.002 \\
& Post-test & & $11.29 \pm 1.254$ & & & \\
\multirow{2}{*}{$36-40$} & Pre-test & 9 & $6.67 \pm 2.449$ & -4.33 & -4.596 & 0.001 \\
& Post-test & & $12.43 \pm 2.030$ & & & \\
\multirow{2}{*}{ Total } & Pre-test & 5 & $6.65 \pm 2.710$ & -4.75 & -3.995 & 0.001 \\
& Post-test & 5 & $11.40 \pm 1.706$ & & & \\
\hline
\end{tabular}

The test results on the level of knowledge difference above indicate that the level of knowledge difference was obtained by participants before and after receiving BLS training. The average level of difference in men's knowledge before and after getting training is -5.71 . The average level of difference in women's knowledge before and after getting training is -4.75 . The average level of difference in knowledge of all participants before and after getting training was -5.18. The degree of difference in knowledge is significant with $\mathrm{p}=0.0001$.
Then the researchers tested the correlation between the level of knowledge and skills with the Pearson Correlation Test and obtained the following results:

Table 5. The Pearson Correlation Test of Knowledge and Skill Level of All Participants

\begin{tabular}{lc}
\hline \multicolumn{1}{c}{ Category } & Correlation \\
\hline Knowledge & 0.170 \\
Skill & 0.088 \\
\hline
\end{tabular}

The results of the correlation test between the level of knowledge and skills in table 5 
show that increasing knowledge does not correlate with increasing levels of skills. That is indicated by the correlation test value which is more than 0.01 on the whole correlation test results.

When the researcher tried to repeat the correlation test based on the level of knowledge and skills, the following results were obtained:

Table 6. The Crosstabs between Knowledge and Skill Level's Correlation Test

\begin{tabular}{lccc}
\hline \multirow{2}{*}{ Skill } & \multicolumn{3}{c}{ Knowledge } \\
\cline { 2 - 4 } Good & Good & Sufficient & Less \\
Sufficient & $0,002^{* *}$ & $0,050^{*}$ & $\mathrm{a}$ \\
Less & $0,045^{*}$ & $\mathrm{a}$ & $\mathrm{a}$ \\
\hline
\end{tabular}

$*$ correlate if $\mathrm{p}<0.05$ (2-tailed)

$* *$ correlate if $\mathrm{p}<0.01$ (2-tailed)

adid not analyze cause there was no posttest knowledge score in sufficient and less level

Table 6 shows that the level of knowledge does not correlate with the level of skills. However, when researchers conducted more correlation tests by separating samples based on ranges of the level of knowledge and skills were well correlated.

Increased knowledge before and after getting training did not only occur in this study. Mayanlambam and Dewi's (2016) research also showed an increase with an average value of knowledge from 24.65 to 35.5, which means that BLS training is effectively effective. The Owojuyigbe et al (2015) study states that $75 \%$ of respondents obtained sufficient BLS knowledge after attending the training. ${ }^{7}$ However, there are a number of studies that have not significantly decreased the value of knowledge after receiving the BLS training, namely the Bhatnagar et al (2017). It happened because of various factors that require further research.

If observed from gender differences, this study gets the value that the knowledge of pre-test and post-test in women has better value than men. In a study conducted by
Sopka et al (2015) in the first week, no significant difference was found in the level of knowledge of both sexes, but at the $8^{\text {th }}$ week, the female group looked superior to the group of male. ${ }^{10}$

In the study of Adrian et al (2017) different results were obtained in the comparison to the value of BLS knowledge of women and men. Adrian et al's research state that women's group are only able to do BLS in less time than the men's group. Also the time needed to start BLS, the women's groups takes longer than the men's groups. The female group also showed a lack of leadership performance in a number of cases included in the CPR case compared to the male group. ${ }^{1}$

Supporting Adrian et al (2017) research, the research conducted by Mario Krammel et al (2018) states that women and elderly participants have low awareness and willingness to conduct BLS training and use Automated External Defibrillators (AEDs) in case of unconsciousness. ${ }^{5}$ Research conducted by Enrico Baldi et al (2015) states that young participants have a good ability to remember BLS, even though the training is only given for a short time. Thus, training provided to young participants is a good provision for training BLS in conducting first aid. ${ }^{3}$

Discussion the correlation between BLS knowledge and skills training, the researchers found a lack of correlation between overall knowledge and skills. Increased knowledge and skills only have a correlation on the value of good knowledge and the value of skills that are quite good. This contradicts research conducted by Seham A. Abd El-Hay et al (2014) which states that there is significant progress on average scores between knowledge and skills in Basic Life Support (BLS) training. ${ }^{4}$

\section{CONCLUSION}


There was an increase in knowledge and skills before and after the provision of BLS (Basic Life Support) training on the Krajan community, Sidodadi Village, Lawang, Malang Indonesia.

\section{REFERENCES}

1. Adrian AS et al. Influence of Gender on the Performance of Cardiopulmonary Rescue Teams: A Randomized. Prospective Simulator Study 2017; 45(7): 1184-1191. Available at: (https://journals.lww.com/ccmjournal/Cit ation/2017/07000/Influence_of_Gender_ on_the_Per formance_of.11.aspx.) (8 October 2018).

2. American Red Cross. Basic Life Support for Healthcare Providers. The American National Red Cross; 2015.

3. Baldi E et al. School Children Learn BLS Better and Less Time Than Adults. The Journal of Resuscitation 2015; 88: 15-16. Available at: (https://www.resuscitationjournal.com/art icle/S0300-9572(15)00018-0/pdf

October 2018).

4. El-hay SAA et al. Effect of Training Program Regarding First Aid and Basic Life Support on the Management of Educational Risk injuries among Students in Industrial Secondary Schools. IOSR Journal of Nursing and Health Science 2015; 4(3): 32-43. Available at:

(http://iosrjournals.org/iosrjnhs/papers/vol4-issue6/Version3/E04633243.pdf) (11 October 2018).

5. Kramel $\mathrm{M}$ et al. Gender and agespecific aspects of awareness and knowledge in basic life support. Journal PloS ONE 2018; 13(6): 179-979. Available at: https://journals.plos.org/plosone/article/fil e?id=10.1371/journal.pone.0198918\&typ e=printabl e (10 October 2018).

6. Mayanlambam P, Devi AM. Knowledge and Practice Regarding Basic Life Support among Nursing Students. International Journal of Research and Review 2016; 3(1): 44-47. Available at: (https://www.researchgate.net/publication /292985105_Knowledge_and_Prac tice_Regarding_Basic_Life_Support_am ong_Nursing_Students\#pf55) (8 October 2018).

7. Owojuyigbe AM, Adenekan AT, Faponie AF, Olateju SO. Impact of Basic Life Support Training on the Knowledge of Basic Life Support in a Group of Nigerian Dental Students. Nigerian Postgraduate Medical Journal 2015; 22(3): 164-168. (8 October 2018).

8. PERKI. Henti Jantung. Indonesian Heart Association Perhimpunan Dokter Spesialis Kardiovaskuler Indonesia

2015. Available at :
(http://www.inaheart.org/education_for_a tient/2015/5/7/henti_jantung). (8 Oktober 2018).

9. Pratiwi ID, Edi P. Basic Life Support: Pengetahuan Dasar Siswa Sekolah Menengah Atas. Universitas Muhammadiyah Malang 2016; 7(2): 9499. (8 October 2018).

10. Sopka S, Bierma H, Rossaint R, Rex, Jager M, Skorning, Heussen N, Beckers SK.. Resuscitation Training In Smallgroup Setting - Gender Matters. Scandinavian Journal of Trauma, Resuscitation and Emergency Medicine 2013. Available at: (https://sjtrem.biomedcentral.com/articles /10.1186/1757-7241-21-30. (8 October 2018) 